\title{
GLOTTODYDAKTYCZNE BEĘDY METODYCZNE
}

Iwona Janowska ${ }^{1}$

\section{BLĘDY METODYCZNE W PLANOWANIU I PROWADZENIU LEKCJI}

\begin{abstract}
Słowa kluczowe: błąd, nauczyciel języków obcych, kształcenie nauczycieli, standardy europejskie, refleksyjność

Streszczenie. Niniejszy artykuł nie jest repertuarem błędów nauczycielskich, chociaż o nich wielokrotnie mowa. Odwołując się do schematu działań nauczyciela w różnych momentach procesu dydaktycznego, nakreślonego w Europejskim Portfolio dla studentów - przyszłych nauczycieli języków koncentrujemy się głównie na takich pytaniach jak: co powinien robić nauczyciel w danej, niekiedy trudnej sytuacji; jaka powinna być jego rola, postawa; czego powinien się wystrzegać, o co szczególnie zabiegać etc. Najbardziej typowe niedociągnięcia i uchybienia (ponieważ wszystkich nikt nie jest w stanie, ani policzyć ani przewidzieć) zostały przedstawione w kontekście negatywnych konsekwencji jakie powodują oraz środków zaradczych, które należy podjąć, by móc uniknąć podobnych nieprawidłowości. Remedium, które okazuje się skuteczne w rozwiązywaniu problemów dydaktycznych spotykanych na co dzień, jest szeroko pojęta refleksja nad własnym warsztatem pedagogicznym oraz doskonalenie zawodowe.
\end{abstract}

\section{WSTĘP}

$\mathrm{Na}$ temat żadnego innego zawodu nie napisano aż tak wiele, jak o nauczycielu. Niemal każdy czuje się kompetentny i upoważniony do komentowania i „oceniania” pracy nauczyciela, do wyrażania opinii na temat, jaki powinien być (dobry) nauczyciel. Na podstawie literatury oraz dyskusji prowadzonych w różnych środowiskach społecznych można stwierdzić, iż

1'iwona.janowska@uj.edu.pl; Katedra Języka Polskiego jako Obcego, Wydział Polonistyki, Uniwersytet Jagielloński, 31-044 Kraków, ul. Grodzka 64. 
oczekiwania i wymagania stawiane tej grupie zawodowej są ogromne, co nie zawsze idzie $\mathrm{w}$ parze $\mathrm{z}$ odpowiedzialnością osób wybierających ten zawód. Konsekwencje niewłaściwego wyboru czy podejścia do zawodu dotykają wielu uczniów, są nieodwracalne, rzutują niekiedy na dokonywane wybory w życiu zawodowym. Nierzadko jesteśmy świadkami wypowiedzi absolwentów szkół, byłych uczestników lektoratów czy kursów, obwiniających swych nauczycieli za mierną znajomość języka obcego, za zdemotywowanie do nauki. Mówią o tym głośno, gdy uświadamiają sobie, z jednej strony, utraconą szansę (setki zmarnowanych i niewykorzystanych godzin języka obcego w szkole), z drugiej zaś, konieczność tu i teraz posługiwania się językiem obcym w kontaktach zawodowych z mieszkańcami krajów Unii Europejskiej, i nie tylko.

Oczywiście, pod żadnym względem nie można twierdzić, że winę za niepowodzenia ponosi wyłącznie nauczyciel. To uczeń uczy się i jeżeli jego stosunek do języka będzie negatywny, na nic zda się wysiłek nawet najlepszego pedagoga. Obarczanie nauczyciela całkowitą odpowiedzialnością za złe wyniki nauki języka jest niesłuszne i krzywdzące. Nauczyciel jest współodpowiedzialny za wyniki złożonego procesu kształcenia językowego. Przypomnijmy chociażby dobrze znany trójkąt pedagogiczny (Hussaye 2014), na którego wierzchołkach figurują: uczeń, nauczyciel i wiedza, a trzy boki figury to ich wzajemne relacje. Tak więc udział nauczyciela w procesie kształcenia językowego jest oczywisty, dlatego wszelkie nieprawidłowości metodyczne mają negatywny wpływ na osiągnięcia uczniów. Jak twierdzi M. Jedynak, „uczeń jest w stanie odnieść sukces w nauce języka obcego, gdy ma kompetentnego nauczyciela. Kwalifikacje nauczyciela, jego osobowość i zaangażowanie mogą zachęcić ucznia do nauki, lub, wręcz przeciwnie, zniechęcić go" (Jedynak 2011, s. 486).

Nawet przy największym wysiłku nauczyciela nie da się wyeliminować wszystkich niedociągnięć, ale można znacznie ograniczyć ich liczbę, zmniejszyć wagę problemu, udoskonalić to, co daje się zmienić. Idea ta jest osią rozważań niniejszego artykułu. Na podstawie obserwacji, badań (zob. np. Dąbrowska i Pasieka 2013) i wieloletniej praktyki oraz głębokiej refleksji nad warsztatem pedagogicznym postaramy się określić sytuacje, dziedziny, podać przykłady nieprawidłowych postaw i działań nauczycielskich, wynikających często ze zwykłej rutyny, braku refleksji w działaniu, które szkodzą uczniom, utrudniają osiąganie pozytywnych wyników. Można wyeliminować wiele błędów pod warunkiem, że nauczyciel jest ich świadomy i stale pracuje nad doskonaleniem swych metod. 


\section{ANALIZA BLĘDÓW W OPARCIU O EPS}

Europejskie portfolio dla studentów - przysztych nauczycieli języków² (EPS) to cenny dokument zawierający opis kluczowych kompetencji nauczycieli języków obcych. Zostały one zdefiniowane w postaci wskaźników biegłości, które podzielono na siedem kategorii. „Reprezentują one dziedziny, które wymagają od nauczycieli wiedzy, posiadania wielorakich kompetencji i umiejętności podejmowania decyzji, dotyczących procesu nauczania" (EPS 2007, s. 4). Dziedziny te tokontekst, metody i techniki nauczania, pomoce dydaktyczne, planowanie lekcji, prowadzenie lekcji, samodzielne uczenie się, ocena wyników nauki. Interesują nas one dlatego, iż obserwowane błędy dotyczyć będą tych właśnie dziedzin. Jeśli Portfolio jest repertuarem wymaganych kompetencji, to błędy są dowodem ich braku lub ich celowego niewykorzystania. Dlatego poszczególne kategorie deskryptorów przyjęliśmy jako główne punkty schematu analizy błędów nauczycielskich.

\subsection{KONTEKST}

Kontekst to program nauczania, cele i potrzeby, rola nauczyciela języka, środki i ograniczenia instytucjonalne. Poważnym uchybieniem w tym obszarze jest nieznajomość treści dokumentów europejskich, takich jak Europejski system opisu czy Portfolio. Mogą one niekiedy wydawać się zbyt trudne i pozornie odległe od rzeczywistości, w której odbywa się kształcenie, wymagają dodatkowego wysiłku ze strony nauczyciela. Jednakże dopiero dogłębna analiza ich zaleceń pozwoli lepiej zrozumieć istotę działań proponowanych uczniom oraz cele stawiane uczącym się na różnych poziomach zaawansowania językowego.

Treści i zalecenia zawarte $\mathrm{w}$ dokumentach krajowych, np. w programach nauczania, w programach kursów, to materiał obowiązkowy do przyswojenia przez każdego nauczyciela. Może warto tutaj przypomnieć, iż wszelkiego typu testy kontrolne powinny być tworzone w oparciu nie o wybrany podręcznik, ale o obowiązujący program. Konsekwencją nieznajomości programu jest brak prawidłowego przygotowania do wymagań stawianych im przez placówkę, w której odbywa się kształcenie.

${ }^{2}$ Dokument ten został opracowany w ramach projektu realizowanego przez Europejskie Centrum Języków Nowożytnych (ECML): Od profilu do portfolio: Model refleksji w kształceniu nauczycieli. 
We wspomnianych powyżej dokumentach określa się zazwyczaj cele nauki, czyli przewidywane rezultaty. Brak znajomości i respektowania celów to droga donikąd. Cele nauczania nie tylko należy znać i realizować, ale także dokonywać ich operacjonalizacji, tzn. przekładać cele ogólne na szczegółowe, realizowane w klasie. Zagadnienie celów wiąże się bezpośrednio z problemem uczniowskich potrzeb, które nauczyciel powinien respektować, jeśli pragnie zmotywować do nauki swoich podopiecznych.

\subsection{METODY I TECHNIKI NAUCZANIA}

Metoda nauczania opiera się na konkretnym podejściu, techniki zaś dotyczą czynności nauczyciela i ucznia w klasie w trakcie procesu nauczania. W procesie dydaktycznym uwzględnia się nie tylko same procedury nauczania i uczenia się, ale też wszelkie pomoce dydaktyczne audialne, wizualne i audiowizualne.

Praca nauczyciela w klasie to, ogólnie rzecz biorąc, działania prowadzące do opanowania przez uczniów podsystemów języka i rozwijania sprawności językowych. Stosowanie różnorodnych technik i procedur ma na celu wspomaganie tego procesu. Wiele niedociągnięć nauczycielskich obserwować można w momencie praktycznego zastosowania teorii dydaktycznych.

Częste stosowanie podejścia dedukcyjnego w prezentacji materiału jest wciąż zjawiskiem nierzadko spotykanym i szkodliwym ze względu na bierność uczących się w trakcie lekcji. Wszystko wyjaśnia nauczyciel bez większego udziału i zaangażowania uczących się. Nie trzeba zbyt wiele wysiłku i inwencji, by odwrócić ten uświęcony tradycją porządek i pozostawić uczniom inicjatywę, tj. odkrywanie tam, gdzie to możliwe, nowych struktur w kontekstach i formułowanie reguł pod czujnym okiem nauczyciela. Wysiłek i zaangażowanie uczniów ułatwia przyswajanie zjawisk językowych.

Powtarzającym się błędem jest poprzestanie na prezentacji słownictwa czy struktur gramatycznych mniemając, że proces ich przyswojenia dokona się sam. Bez „treningu” uczeń nie potrafi zastosować w praktyce poznanej wiedzy. Potrzebne są intensywne ćwiczenia rozłożone w czasie, aby uczeń mógł swobodnie posługiwać się wyuczoną strukturą w komunikacji. Po prezentacji, seria ćwiczeń i zadań pozwala zgłębić problem, zaś powrót do struktur po kilku (czy kilkunastu) lekcjach umożliwia ich trwałe zapamiętanie. Nauczyciel musi pamiętać również o tym, by nauczanie gramatyki nie stało się celem samym w sobie, by traktować ją jako element ułatwiający komunikację.

W nauczaniu słownictwa, gramatyki oraz innych podsystemów języka, drogą do uzyskania dobrych efektów jest budowanie nowej wiedzy i umiejętności na bazie tych, które zostały już przyswojone przez uczniów (budujemy na tym, 
co znane). Rozpoczynanie lekcji (fazy lekcji) bez uprzedniego zorientowania się, co uczący się potrafią robić w danym języku jest marnowaniem szansy włączenia ich do procesu dydaktycznego, wykorzystania tkwiącego w nich potencjału językowego.

Mając na względzie rozwijanie kompetencji różnojęzycznej i różnokulturowej, należy od pierwszych lekcji przyzwyczajać uczniów do stosowania strategii odgadywania znaczeń oraz rozpoznawania form gramatycznych na podstawie ich podobieństwa do struktur (zagadnień) w innych znanych im językach.

\subsubsection{Działania językowe}

Jak już wspominano, procedury stosowane przez nauczyciela mają za zadanie wspomagać przyswajanie języka, jego słownictwa, gramatyki, wymowy i ortografii. Przedmiotem refleksji zamieszczonych poniżej będą procedury najczęściej stosowane przy rozwijaniu sprawności językowych: rozumienia ze słuchu, czytania ze zrozumieniem, pisania i mówienia. Chociaż w literaturze przedmiotu najczęściej się je rozdziela, by dokonać ich szczegółowego opisu, w praktyce rozwija się je w sposób zintegrowany.

Wypowiedzi ustne to różne typy tekstów tworzonych przez uczących się, od prostych pojedynczych zdań, poprzez odgrywanie ról, dyskusje, dialogi, do dłuższych samodzielnych wypowiedzi, takich jak np. prezentacje. Mówienie uchodzi za najbardziej złożony typ działań językowych, dlatego wymaga dobrej i życzliwej atmosfery, zachęcającej uczniów do wypowiadania się. Nauczyciele często zapominają, że reakcje słowne następują pod wpływem odpowiedniego bodźca, którym mogą być polecenia i sugestie nauczyciela, zachowania werbalne i niewerbalne kolegów, teksty podręcznikowe i pozapodręcznikowe, ilustracje, filmy, słuchowiska etc. Tworząc wypowiedzi, biorąc udział w dyskusji, wypowiadając swoje opinie, uczący się powinni umiejętnie stosować strategie komunikacyjne, a nauczyciel powinien stale zwracać uwagę na ten aspekt produkcji ustnej.

Reasumując, w trosce o aktywność grupy, nauczyciel powinien: dostarczać uczniom bodźców do wypowiadania się, stosownie do ich wieku i zainteresowań, stosować procedury zachęcające do wypowiadania się, dyskretnie kierować działaniami uczniów i czuwać nad poprawnością wypowiedzeń, nie zniechęcać, nie onieśmielać, nie ośmieszać nikogo, akceptować wszystkie możliwe opinie nawet te niezgodne $\mathrm{z}$ treścią tekstu - w fazie przygotowania do jego odbioru, pozostawić uczniom swobodę, ingerować jak najrzadziej, pozwolić im mówić, nie przerywać w celu poprawienia wszystkich błędów.

Działania receptywne (słuchanie i czytanie) omawiamy łącznie, ponieważ mają wiele cech wspólnych. Obydwie sprawności wymagają właściwego doboru 
tekstów, stosownie do potrzeb, zainteresowań i poziomu językowego uczących się. Należy zwrócić uwagę na odpowiednią długość dokumentu słuchanego czy czytanego: zbyt długi tekst nie motywuje, nie sprzyja koncentracji, a zapamiętanie informacji jest utrudnione.

Należy zawsze przygotować uczniów do odbioru tekstu, niezależnie od tego w jakiej postaci zostanie im zaprezentowany. Wielu nauczycieli pomija tę bardzo istotną fazę lekcji, pozbawiając uczniów nie tylko działań poznawczych, ale i niekiedy dobrej zabawy. Zadaniem fazy aktywizacji jest motywowanie do wysłuchania/przeczytania tekstu, uruchamianie wiedzy i strategii rozumienia oraz formułowanie celów rozumienia. W przypadku odbioru obydwu typów tekstów, nauczyciel powinien nauczyć swoich podopiecznych stosowania strategii domyślania się znaczeń na podstawie pragmalingwistycznych i paratekstowych środków wyrazu. Niezwykle cenna jest umiejętność odwoływania się do innych, znanych uczniom języków oraz do słów transparentnych.

W trakcie słuchania/czytania i/lub po nim należy sprawdzić różne typy rozumienia (globalne, selektywne, szczegółowe). W przypadku obydwu sprawności liczba procedur stosowanych w tym celu przez nauczyciela jest nieograniczona. Jednak często stykamy się z sytuacją, kiedy to uczący się wykonują jedno ćwiczenie o charakterze zamkniętym i bliżej nieokreślonym celu; na tym nauczyciel kończy cały, dość skomplikowany proces rozumienia. Po słuchaniu i czytaniu należy przejść do serii ćwiczeń/zadań pozwalających utrwalić nowo poznane elementy językowe oraz rozwijać inną sprawność (najczęściej produktywną) lub wykorzystać tekst w działaniu. Z przykrością stwierdzamy jednak, że do tej ostatniej fazy kształcenia działań receptywnych wielu uczących nie dochodzi.

Kształcąc sprawność pisania, zacznijmy od pytania, jakie typy wypowiedzi pisemnych stosują dzisiaj uczący się. To głównie różnego typu e-maile i sms-y. Ich zasadniczą cechą jest krótka, komunikacyjna i zwarta forma. Na lekcjach języka trzeba uczyć tworzyć krótkie teksty i na nie odpowiadać, dostarczając uczniom na początku gotowych wzorców i modeli wypowiedzi. Nie oznacza to wcale, że pomijamy w nauczaniu takie formy pisemne, jak różnego typu listy, sprawozdania, opisy, recenzje etc. Formy te są powszechnie wymagane na egzaminach. Problem jednak polega na tym, iż przy ograniczonej liczbie godzin języka trudno jest rozwijać dłuższe formy wypowiedzi pisemnej. Pozostaje więc nauczycielowi, po uprzednim omówieniu formy wypowiedzi pisemnej i serii ćwiczeń w zakresie pisania kontrolowanego i/lub sterowanego, zlecać je jako pracę domową.

Podejście nauczyciela do zadań domowych musi być niezwykle rzetelne i konsekwentne. Jeśli prosimy o tworzenie wypowiedzi pisemnej, szczegółowo informujemy: jak dana praca powinna wyglądać, co powinna zawierać, jaka ma być jej długość i w jakim terminie zadanie musi zostać wykonane. Nauczyciel zyskuje wiele, jeśli planuje zadanie domowe tak, aby stanowiło ono „,przedłużenie lekcji”. Z reguły uczniowie systematycznie wykonujący zadania nie narzekają na 
brak czasu, przyjmują to jako fakt oczywisty, wymagają tylko, by nauczyciel zainteresował się ich pracą, poprawił, ocenił, wskazał, jak rozwiązywać trudności.

Niezwykle cenną procedurą jest wspólne poprawianie niektórych błędów (prac), aby uczniowie uczyli się zasad, reguł od swoich kolegów. Podczas wspólnej poprawy zadań uczący się otrzymuje informację zwrotną na temat swoich niedociągnięć i szybciej może uwolnić się od trudności.

W przypadku prac domowych najgorszym błędem nauczyciela jest ich lekceważenie, niesprawdzanie lub sprawdzanie zbyt pobieżne, oddawanie uczniom prac po kilku tygodniach od ich napisania. W takim wypadku zadanie nie spełnia już swej roli, poprawa błędów nie ma sensu, ponieważ uczący się zdążyli już o wszystkim zapomnieć, pracując na lekcji nad kolejnymi partiami materiału. Konieczne jest więc przestrzeganie zasady: zadaję zadanie - sprawdzam je w maksymalnie krótkim czasie - omawiamy błędy - wyciągamy wnioski; nie znajduję czasu na sprawdzanie zadań - nie zadaję prac domowych.

\subsubsection{Kształcenie kompetencji interkulturowej}

Materiały nauczania są nacechowane kulturą języka docelowego, dotyczy to zarówno tekstów, jak i elementów graficznych zamieszczanych w podręcznikach. Jednakże ta wiedza kulturowa nie może być przyswojona bez pomocy mediatora-nauczyciela, który potrafi ją wyjaśniać, komentować i przybliżać uczniom rozmaite fakty. Nauczyciel powinien rozbudzać zainteresowanie kulturą kraju języka docelowego, porównywać ją z kulturą rodzimą uczących się i innymi kulturami, pomagać w odkrywaniu podobieństw i różnic kulturowych, zwalczać stereotypy, uczyć tolerancji i rozumienia różnorodnych zachowań, zachęcać do pogłębiania znajomości elementów kulturowych (bez których trudno niekiedy zrozumieć język), wskazywać na powiązania między kulturą a językiem.

Brak czasu nie zwalnia nauczyciela z funkcji „,mediatora kulturowego”, ponieważ w trakcie lekcji jest wiele okazji do zwrócenia uwagi na pewne istotne fakty, udzielenia krótkich wyjaśnień i komentarzy, zachęcenia uczniów do poszerzenia wiedzy w oparciu o materiały internetowe.

\subsection{MATERIAŁY I POMOCE DYDAKTYCZNE}

Główną pomocą na każdym kursie językowym jest podręcznik. Jego specyficzna konstrukcja zapewnia ciągłość materiału, pozwala powracać do analizowanych już problemów, uczeń czuje się pewniej, mając w zasięgu taki całościo- 
wy repertuar zagadnień językowo-kulturowych. Jednakże wybór odpowiedniego podręcznika stanowi nie lada problem, szczególnie w nauczeniu języka polskiego jako obcego. W sytuacji jeszcze nadal dość dużego deficytu tych pomocy dydaktycznych lektorzy podejmują błędne decyzje, kierując się często rynkową popularnością proponowanych serii metodycznych czy przyciągającą szatą graficzną. Niejednokrotnie wystarczy im zgodność poziomu zaawansowania deklarowanego przez autorów podręcznika i prowadzonej grupy, a to jak wiadomo, nierzadko się nie pokrywa.

O podręcznikach można by pisać bardzo wiele, ale nie chodzi tutaj o ich charakterystykę. Pragniemy zwrócić jedynie uwagę na niektóre konsekwencje nieodpowiedniego doboru podręcznika przez nauczyciela. Pierwszy problem ma charakter psychologiczny. Gdy okazuje się, że z danym podręcznikiem trudno jest pracować na lekcji (jest za łatwy, za trudny, za mało w nim materiału językowego, brak odpowiednich zadań i ćwiczeń etc.) następuje osłabienie zainteresowania jego zawartością i zarówno nauczyciel, jak i uczniowie niechętnie po niego sięgają. W takiej sytuacji zakup nowego podręcznika też jest w zasadzie niemożliwy, bo w grę wchodzi czynnik ekonomiczny. Kolejna niedogodność, tym razem o charakterze metodycznym, to dodatkowe obciążenie nauczyciela, który musi modyfikować, uzupełniać wybrany przez siebie podręcznik, dostosowując go do potrzeb swoich uczniów. Wyszukanie materiałów zastępczych, ich dydaktyzacja, włączenie do obowiązującego planu nauczania, opracowanie odpowiednich zadań i ćwiczeń jest z natury trudne i czasochłonne.

Tak więc nauczyciel musi posiadać umiejętność doboru właściwych podręczników dla swoich uczniów w oparciu o program nauczania, koncentrując się głównie na jego językowo-kulturowych treściach. Stosowanie dodatkowych materiałów nauczania (poza podręcznikiem), uznanych przez nauczyciela za motywujące, wiąże się z koniecznością ich „obróbki” metodycznej, czyli adaptacji do danych warunków nauczania. Wiedza tego typu powstaje w wyniku praktyki i głębokiej refleksji w sytuacji podejmowania decyzji. Kurczowe trzymanie się podręcznika nie należy również do zalet, gdyż koncepcja jego autorów niekoniecznie idzie $\mathrm{w}$ parze $\mathrm{z}$ zainteresowaniami i potrzebami uczących się.

I na koniec warto jeszcze zauważyć, iż bardzo niebezpiecznym zjawiskiem jest obojętność nauczyciela na to, co znajduje się w podręczniku, niekiedy mocno zdezaktualizowanym. Wówczas prowadzący realizuje jednostkę po jednostce, uczniowie wykonują zawarte w nich ćwiczenia, bez jakiejkolwiek refleksji i odniesienia do programu nauczania czy wskaźników biegłości językowej ESOKJ. 


\subsection{PLANOWANIE LEKCJI I KONSTRUOWANIE ZADAŃ}

Ogromne zróżnicowanie form kształcenia językowego oraz uczących się (ich potrzeb, zainteresowań) powodują, iż nauczycielskie planowanie stało się procesem skomplikowanym. Dlatego wielu nauczycieli stara się obejść ten problem i zamiast właściwie planować kurs, posługuje się np. spisem treści podręczników. „Plany” takie często nie uwzględniają specyficznych warunków nauczania języka, w jakich pracuje dany nauczyciel. Materiały nauczania zaś nie zawsze odzwierciedlają potrzeby i możliwości uczniów danej społeczności (szkoły, klasy, grupy), ponieważ są adresowane do wielonarodowościowej publiczności.

Mimo licznych niedogodności od samego początku pracy w zawodzie nauczycielskim warto podjąć trud stopniowego przyswajania sztuki planowania, konstruowania programów, planów kursów i jednostek metodycznych, konspektów lekcji, ćwiczeń i zadań. Od wieków pomocne są tutaj pytania Kwintylia$\mathrm{na}^{3}$, które można odnieść do każdej sytuacji nauczania. Nieuwzględnienie tych danych w tworzonych planach (lekcji czy kursów), stawia rzetelność planowana pod znakiem zapytania (zob. Janowska 2015). Punktem wyjścia w doborze celów, treści nauczania, typów zadań i ćwiczeń jest program nauczania, a nie stosowany podręcznik. Cele ogólne, zawarte w programie, należy przekształcić na cele operacyjne, szczegółowe, a to często nastręcza wiele trudności. Aby zilustrować ten problem, posłużymy się tu następującym przykładem: zoperacjonalizujemy wskaźnik biegłości językowej dla poziomu B1 w zakresie czytania ze zrozumieniem. „Rozumiem teksty składające się głównie ze słów najczęściej występujących, dotyczących życia codziennego lub zawodowego" (ESOKJ 2003, s. 34). Wprawdzie nie jest to cytat z programu, lecz fragment Systemu opisu, ale jego ogólny charakter wymaga szczegółowego zaplanowania szeregu działań, które pomogą uczącemu się ten cel osiągnąć. Należy więc: określić najistotniejsze sytuacje z życia codziennego lub zawodowego, dobrać teksty odpowiadające tym sytuacjom i zawierające podstawowe słownictwo $\mathrm{z}$ danego zakresu, skonstruować ćwiczenia i zadania umożliwiające opanowanie nowego słownictwa i struktur gramatycznych.

${ }^{3} \mathrm{CO}$ ? Treści nauczania: lingwistyczne, komunikacyjne, kulturowe, literackie (techniczne, naukowe - gdy język obcy jest stosowany w nauczaniu różnych dyscyplin).

KTO? Uczestnicy procesu dydaktycznego i ich role: uczniowie i ich koledzy, nauczyciele i ich koledzy, rodzimi użytkownicy języka etc.

GDZIE? KIEDY? Okoliczności/sytuacje nauczania: kraj, instytucja, wiek uczących się, czas trwania i typ kursu.

DLACZEGO? Cele nauczania: cele stawiane przez uczniów i nauczycieli, wymagania egzaminacyjne.

W JAKI SPOSÓB? Metody: metody i techniki w ramach podejścia, strategie nauczania i uczenia się. 
Już na pierwszy rzut oka dostrzec można, iż ten krótki i prosty deskryptor implikuje kilka etapów planowania, z których każdy obejmuje pewną liczbę jednostek lekcyjnych.

W konstruowanym planie powinny zostać przewidziane takie pomoce/środki (teksty ciągłe, dialogi, informacje, schematy etc.), które ułatwią nauczycielowi wprowadzenie nowego materiału, a uczniowi jego zapamiętanie. Odpowiednio dobrane zadania i ćwiczenia, czyli manipulowanie nowo poznanymi strukturami, doprowadzi do osiągnięcia celu: ich opanowania i wykorzystania w (nowej) sytuacji komunikacyjnej.

Aby poprawnie zbudować swój plan, nauczyciel musi sprecyzować: jakie cele sobie stawia, jakie treści implikują wyznaczone cele oraz w jaki sposób zamierza je osiągnąć (materiały, metody, techniki, zadania, ćwiczenia). Cele ogólne i operacyjne powinny zawsze uwzględniać potrzeby i zainteresowania uczniów. Planując, należy zadbać o spójność, a zarazem o różnorodność procesu. Plan spójny znaczy zogniskowany na jakimś problemie, zróżnicowany, znaczy uwzględniający rozwijanie podstawowych kompetencji w oparciu o rozmaite środki i materiały, zadania i ćwiczenia.

Jeśli chodzi o niedociągnięcia w nauczycielskim planowaniu, najczęściej zauważa się brak rzetelnie zbudowanego planu wynikowego, brak spójności celów, metod i środków, „realizowanie” podręcznika, nieumiejętność konstruowania ćwiczeń i zadań. Umiejętność planowania zadań jest pierwszoplanowym wymogiem współczesnej dydaktyki. Zadanie to wielofunkcyjne narzędzie dydaktyczne, podstawowa jednostka nauczania, uczenia się i ewaluacji. Pozwala ono nie tylko wprowadzać i stosować struktury językowe, ale również zmieniać i unowocześniać stare podręczniki poprzez włączanie nowych tekstów wraz z sekwencjami opracowanych zadań (zob. Janowska 2012). Aby móc poprawnie konstruować zadanie, nauczyciel musi przede wszystkim zrozumieć jego istotę, umiejętnie sformułować polecenie i wkomponować zadanie w realizowaną jednostkę. Autorzy Europejskiego portfolio dla studentów - przyszłych nauczycieli języków wyjaśniają, iż prawidłowy dobór zadań wymaga użycia różnych umiejętności i kompetencji, zapewnia współzależność słuchania, czytania, mówienia i pisania oraz współzależność języka i kultury, łączy gramatykę i słownictwo z komunikacją, zwiększa i podtrzymuje motywację i zainteresowania uczniów (EPS 2007, s. 30).

Kolejny problem to różnicowanie zadań w celu wykorzystania wiedzy i umiejętności posiadanych przez uczących się, zwiększenia motywacji, uwzględnienia różnych stylów uczenia się. Obserwacje z realizacji zaplanowanych zadań stanowią wskazówki do planowania kolejnych lekcji. Zadania należy tak planować, by umożliwiały stosowanie różnych form organizacyjnych zajęć (praca równym frontem, w grupach, w parach) oraz różnych typów interakcji między uczniami. 


\subsection{PROWADZENIE LEKCJI (KIEROWANIE PRACĄ LEKCYJNĄ)}

Sformułowania „przebieg lekcji”, „prowadzenie lekcji”, „,kierowanie pracą lekcyjną/procesem lekcyjnym" etc. - to pojęcia bardzo ogólne, pod którymi kryją się różnorodne zachowania i postawy uczestników procesu dydaktycznego. Działania nauczyciela i uczniów określa się w sposób bardzo ogólny w planie czy konspekcie lekcji. Mimo iż nie oddaje on całej złożoności procesu nauczania/uczenia się, jest wyznacznikiem działań i barierą bezpieczeństwa. Rzetelnie sporządzony plan, przemyślany, logiczny, a zarazem elastyczny zapewnia prawidłowość procesu lekcyjnego. Szczegółowy scenariusz lekcji zapisany w konspekcie może z łatwością ulec zakłóceniu przez nieprzewidziane okoliczności czy zachowania uczniów (np. trudności uczniów w opanowaniu danego materiału lub nieprzewidziane zainteresowanie pewnymi zagadnieniami). Konieczność modyfikacji planu wymaga dużej elastyczności ze strony nauczyciela, ponieważ jego bezradność, niepewność spowoduje chaos, stratę czasu lekcyjnego, rozluźnienie dyscypliny, bezsensowne procedury etc. Umiejętność radzenia sobie z nieprzewidzianymi sytuacjami w klasie trzeba stopniowo wypracowywać. Przede wszystkim nie można stracić z oczu celu (celów) lekcji, a działania ogniskować na najistotniejszych problemach. Konspekt podpowiada rozwiązania nawet wówczas, gdy trzeba szukać procedur zastępczych. Pozwala on również rozłożyć prawidłowo w czasie poszczególne zadania, ćwiczenia i działania.

Brak przemyślanego planu, gorączkowe szukanie tekstów, zadań, poleceń, działania niezgodne z wyznaczonymi celami, nielogiczne, etc. dają się łatwo zaobserwować przez uczących się. Tego typu niedociągnięcia powtarzają się nader często na zajęciach z języka i świadczą o nieprzygotowaniu nauczyciela do lekcji. Częstym błędem jest również rozpoczynanie lekcji bez uprzedniego odwołania się do wiedzy i umiejętności uczniów. Uczeń nauczy się tylko tego, co nie jest mu obce, z czym się już zetknął. Obecnie, ze względu na mobilność ludności, na każdym poziomie nauczania obserwuje się duże zróżnicowanie umiejętności językowych uczących się. Wstępne działania poprzedzające pracę na nowym materiale są z jednej strony wskaźnikiem dla nauczyciela, co uczniowie już umieją, z drugiej zaś stwarzają szansę uczenia się od innych, korzystania z ich umiejętności.

\subsection{SAMODZIELNE UCZENIE SIĘ}

Niezależnie od sytuacji, zarówno uczący się języka w szkole jak i poza szkołą, musi podjąć trud samodzielnego uczenia się. Ta autonomia sensu largo przybiera różne formy w konkretnych sytuacjach kształcenia językowego. 
Często tygodniowy wymiar godzin języka (2-4) to zbyt mało czasu, by przyswoić bogaty materiał językowy. Na każdym poziomie wymagana jest praca samodzielna jako dopełnienie i poszerzenie procesu lekcyjnego. Na niższych poziomach nauczania jest ona $\mathrm{z}$ reguły organizowana i kierowana przez nauczyciela. Im starsi uczący się i im wyższy poziom zawansowania językowego, tym pomoc nauczyciela jest mniej konieczna, zmniejsza się jego udział w kierowaniu procesem aż do całkowitego zaniechania tej roli. Uczący się rozwinęli już na tyle umiejętność samodzielnego uczenia się, że bez pomocy mogą zrobić notatkę, przeczytać artykuł prasowy, znaleźć materiały w internecie. „Autonomiczne uczenie się jest integralną częścią przyswajania języków obcych, a nie kolejną metodą nauczania. Nauczyciele powinni wiedzieć, w jaki sposób zaplanować zajęcia i zaprojektować zadania, które będą wspierać uczniów w dokonywaniu wyborów i skutkować rozwijaniem zdolności refleksji nad procesem uczenia się i samooceny" (EPS 2007, s. 39). W świetle tego cytatu, poważnym niedociągnięciem jest sytuacja, gdy nauczyciel nie umie lub nie ma ochoty organizować samodzielnego uczenia się, w wyniku czego uczniowie nie są do niej stopniowo przygotowywani. Cały proces przebiega tak, jakby nauczanie przebiegało wyłącznie w salach lekcyjnych, tymczasem „to nauczyciel ponosi odpowiedzialność za stworzenie uczniom możliwości przyswajania języka poza klasą" (ibidem, s. 39).

Istotną rolę w kształtowaniu autonomii odgrywają nowoczesne technologie. Dla młodych ludzi są to ciekawe i motywujące materiały i sposoby uczenia się. Natomiast w oczach nauczyciela bywają często synonimem dodatkowego obowiązku i utrudnienia pracy ze względu na problemy lokalowe, brak znajomości systemów informatycznych, konieczność przeznaczenia dodatkowego czasu na przegląd i wyszukanie odpowiednich materiałów dla danej grupy uczących się. $\mathrm{Z}$ ogromną szkodą dla uczących się nauczyciel często rezygnuje z tego banku materiałów lub proponuje uczniom korzystanie z niego według własnego uznania. Chcąc, by jego uczniowie osiągali dobre wyniki i kontynuowali naukę języka poza szkołą, nauczyciel musi systematyczne wdrażać ich do autonomii, stopniowo rozwijać u nich savoir-apprendre ${ }^{4}$.

Podsumowując, to od nauczyciela uczeń musi nauczyć się samodzielnego wykonywania zadań, które pozwolą mu planować własną naukę zgodnie z jego potrzebami, zachęcą do refleksji nad własnym uczeniem się, pomogą stosować odpowiednie strategie oraz wykształcić nowe. W osiąganiu samodzielności i umiejętności refleksji nad własnym uczeniem się pomocne są również prace projektowe, korzystanie z portfolio, zajęcia pozalekcyjne, spotkania z rodzimymi użytkownikami języka.

${ }^{4}$ umiejętność uczenia się - jedna z kompetencji ogólnych użytkownika języka wyróżnionych przez ESOKJ obok: wiedzy (svoir), umiejętności (savoir-faire) i cech osobowościowych (savoir-être). 


\subsection{KONTROLA I OCENA WYNIKÓW NAUKI}

Ocenianie zawsze postrzegane było jako czynność trudna i odpowiedzialna, a zarazem niezbędna do prawidłowego przebiegu procesu nauczania/uczenia się. W dobie niezwykłej popularności sprawdzianów pisemnych, testów, kartkówek etc. nie należy zapominać, że znajomość języka nie polega na umiejętności wstawiania poprawnej formy gramatycznej w luki, ani też na zakreślaniu poprawnych odpowiedzi w pytaniach wyboru czy typu prawda/fałsz. Rozumienie i tworzenie wypowiedzi ustnych, reagowanie w rozmaitych sytuacjach komunikacyjnych etc., to z pewnością działania bardziej kompleksowe niż ćwiczenia leksykalnogramatyczne. Brak zadań kontrolnych z zakresu ustnych działań interakcyjnych i produktywnych oznacza jednostronną, częściową ewaluację poziomu znajomości języka. Przedmiotem kontroli i oceny powinny być nie tylko znajomość gramatyki i słownictwa, ale wszystkie działania językowe.

Rzetelna kontrola i ocena wymaga dużego wkładu pracy ze strony nauczyciela, jego samodyscypliny, zapoznania się z procedurami oceniania, zastosowania kryteriów zgodnie z realizowanym materiałem programowym. Każda z umiejętności językowych wymaga nie tylko stosowania odmiennych technik i procedur w procesie nauczania, zasada ta dotyczy również ewaluacji.

Współczesne materiały nauczania proponują szereg narzędzi kontroli i ewaluacji zamieszczonego w nich materiału językowego. Dotyczy to zarówno kontroli bieżącej, jak i okresowej. Nauczyciel musi je bardzo umiejętnie dobierać i stosować w zależności od celu i typu kontroli. Rażącym błędem jest nieodpowiedni dobór narzędzi ewaluacji i np. korzystanie z kryteriów oceny sprawności produktywnych, stosowanych na egzaminach (ocenianie sumaryczne) w trakcie kontroli bieżącej o charakterze kształtującym. W tym wypadku należy tworzyć własne siatki oceny, uwzględniające typ zadania i jego cel - językowy, pragmatyczny, socjolingwistyczny czy kulturowy. W tym wypadku można konstruować własne narzędzia kontroli w oparciu o deskryptory ESOKJ (zob. Janowska 2014).

Niezależnie od okoliczności i warunków kształcenia, kontrola musi być systematyczna i prawidłowo zorganizowana. Najczęściej obserwuje się tutaj następujące błędy: całkowite przerzucenie ciężaru powtórzenia materiału na uczniów; brak precyzji, co będzie przedmiotem kontroli; stosowanie gotowych testów bez sprawdzenia, czy obejmują one materiał opracowany na lekcji; zbyt długi okres oczekiwania na poprawę i wyniki testu; nierzetelne oceny powstałe przy zastosowaniu nieodpowiednich kryteriów; zaniechanie analizy błędów i szukania ich źródła przy współudziale uczących się.

Kontrola i ocenianie to dziedzina niezwykle delikatna, a brak rzetelności nauczyciela może mieć bardzo negatywne skutki jeśli chodzi o motywację do nauki oraz kształtowanie pozytywnych postaw uczących się. Każdy uczący powinien 
stale zadawać sobie pytania: „co oceniać, kiedy oceniać, jak oceniać i w jaki sposób wykorzystywać informacje uzyskane w procesie dokonywania oceny w celu wspierania nauki i poprawienia jakości nauczania” (EPS 2007, s. 46).

\section{REFLEKSYJNOŚĆ NAUCZYCIELA - SPOSÓB NA UNIKANIE BŁĘDÓW}

Nauczyciel języków obcych nie jest dzisiaj tym, kim był kiedyś, a to ze względu na zmiany w edukacji, których jesteśmy świadkami: standardy kształcenia wciąż się zmieniają, nowoczesne technologie dominują nauczanie, uczniowie pełnią rolę usługobiorcy, struktury i formy kształcenia (cykle, moduły etc.) są coraz bardziej kompleksowe, ewaluacji przypisuje się rolę kształcącą, dydaktyka jest równie zróżnicowana jak potrzeby uczących się. W tej sytuacji trudny zawód nauczyciela języków staje się jeszcze bardziej wymagający. Jednym ze sposobów radzenia sobie z wyzwaniami, jakie stoją przed nauczycielem, jest refleksyjne podejście do procesu nauczania/uczenia się.

We współczesnej literaturze przedmiotu akcentuje się mocno rolę refleksyjnej praktyki w doskonaleniu zawodowym nauczycieli. Wspominane wielokrotnie $E \mathbf{E}$ ropejskie portfolio dla studentów - przyszłych nauczycieli języków może stać się źródłem konstruktywnej refleksji nie tylko dla tych, którzy przygotowują się do pracy w zawodzie nauczyciela. We wprowadzeniu do tego dokumentu czytamy, iż jego głównym celem jest zachęcenie użytkowników do refleksji na temat ich wiedzy i umiejętności dydaktycznych (EPS 2007, s. 7). Uzupełniając intencje autorów EPS, możemy stwierdzić z całą stanowczością, iż konieczność kształtowania postawy refleksyjnej dotyczy nie tylko studentów i początkujących nauczycieli. Refleksja musi nieodłącznie towarzyszyć każdemu nauczycielowi na przestrzeni całej jego kariery zawodowej, a Portfolio może w tym być bardzo pomocne.

Czy zatem refleksja jest po prostu myśleniem o tym, co zamierzamy robić, co robimy i co będziemy robić? Każde kompleksowe działanie wymaga refleksji. Praktyka refleksyjna jest rozumiana jako refleksja na temat sytuacji, celów, środków, podejmowanych działań, rezultatów i ewentualnych zmian w systemie działania. W literaturze przedmiotu wyróżnia się dwa typy refleksji: refleksję w działaniu oraz refleksję na temat działania (Schön 1994). Refleksja w działaniu polega na zastanawianiu się nad tym, co się dzieje lub będzie się działo, co można zrobić, co trzeba zrobić, jaka taktyka jest najlepsza, jakie środki ostrożności trzeba podjąć, jakie ryzyko się z tym wiąże. Refleksja na temat działania to coś zupełnie innego. Ma ona miejsce wówczas, gdy własne działanie czynimy przedmiotem refleksji, by np. porównać je z modelem, wzorcem, z tym co powinno się robić lub można było zrobić, z tym, co inny praktyk byłby zrobił, bądź też po to, by 
wyjaśnić lub skorygować działanie. Refleksja nie ogranicza się do przypomnienia, przywołania faktów, ale poddana jest krytyce, analizie, porównaniu, odwołaniu się do reguł, teorii lub innego działania, abstrakcyjnego, tj. wyobrażonego lub przeprowadzonego w analogicznej sytuacji. Ph. Perrenoud (2012, s. 35) pisze o refleksji retrospektywnej i prospektywnej.

Spontaniczna refleksja na temat działania zdarza się każdemu, ale takie stawianie pytań samemu sobie, zastanawianie się, nie jest ani metodyczne ani regularne i niekoniecznie prowadzi do uświadomienia sobie pewnych faktów i w konsekwencji do zmian. Refleksyjny praktyk nie zadowala się tym, czego nauczył się w trakcie studiów, ani też tym, co odkrył w pierwszych latach swej pracy zawodowej. Stale analizuje swoje cele, metody, strategie, wiedzę. Sam lub przy wsparciu kolegów nauczycieli teoretyzuje swoją praktykę. Zastanawia się, stara się zrozumieć swoje niepowodzenia, myśląc o przyszłości, przewiduje, co zrobi inaczej, wyraźniej i jaśniej formułuje swoje cele i oczekiwania. Refleksja to systematyczna praca nad sobą, umożliwiająca konstruowanie nowej wiedzy, która wcześniej czy później zostanie przełożona na działanie.

Postawy refleksyjnej nie nabywa się spontanicznie, trzeba ją kształtować i rozwijać w procesie doskonalenia zawodowego, łącząc poszerzanie wiedzy z doskonaleniem umiejętności działania. Taka postawa refleksyjna pozwala dokonywać analizy metodycznej, regularnej, instrumentalnej, przynoszącej efekty. Tego typu dyspozycje i kompetencje nabywa się wskutek intensywnego i celowego treningu.

Refleksyjność nie jest tylko kompetencją w służbie dobrze pojmowanych interesów nauczyciela, ale przejawem odpowiedzialności zawodowej. Nauczyciel, który ucieka się do refleksji z konieczności i przestaje myśleć, gdy tylko czuje się bezpieczny, nie jest praktykiem refleksyjnym. Postawa i praktyka refleksyjna prowadzą do przeżywania nauczania w sposób pozytywny, do aktywnego organizowania tego procesu i osiągania czegoś więcej niż podstawowe minimum. Rozwijać praktykę refleksyjną znaczy uczyć się wyciągać korzyści z refleksji, a mianowicie dopracowywać schematy działania, pozwalające na szybszą interwencję, bardziej celową i bardziej pewną; wzmacniać własny wizerunek jako refleksyjnego zawodowca, który ewoluuje; gromadzić wiedzę, która pozwoli zrozumieć inne problemy zawodowe.

Refleksja bez oparcia na odpowiedniej wiedzy nie prowadzi zbyt daleko. Pojedyncze doświadczenie powoduje uczenie się tylko wtedy, gdy jest ono połączone $\mathrm{z}$ wiedzą, która czyni je zrozumiałym, i wpisuje się w taką czy inną regularność. „Refleksja jest na ogół bardziej płodna, jeśli karmi się lekturą, doskonaleniem, wiedzą teoretyczną czy zawodową skonstruowaną przez innych, badaczy lub praktyków" (Perrenoud 2012, s. 50). 


\section{PODSUMOWANIE}

Jak wynika z powyższych rozważań, powszechność nauczania języków w dzisiejszym świecie i wszechobecność nowoczesnych technologii informacyjnych nie idą w parze $\mathrm{z}$ pomniejszeniem nauczycielskich obowiązków, lecz sugerują zupełnie coś przeciwnego. Są one symbolem zwiększonych wymagań w stosunku do nauczyciela, wymagań stawianych zarówno przez uczniów, jak i pracodawców. Sprostanie tym wymogom wymaga stałego doskonalenia się, poszerzanie wiedzy formalnej i instrumentalnej, nabytej poprzez refleksyjną praktykę. Nauczyciel musi znać rozporządzenia, standardy wymagań, minima programowe, czytać i interpretować dokumenty krajowe i europejskie, umieć się nimi posługiwać. Na bieżąco śledzić zmiany w systemach edukacji w kraju i tendencje europejskie. To sugeruje konieczność systematycznego czytania prasy pedagogicznej, uczestniczenia $\mathrm{w}$ różnych formach doskonalenia zawodowego: konferencjach, seminariach, kursach. Jak podkreślaliśmy wielokrotnie, doskonalenie warsztatu pedagogicznego to nie tylko poszerzanie, wzbogacanie wiedzy teoretycznej, ale także (a może przede wszystkim) refleksja nad własną praktyką - szukanie przyczyn niepowodzeń czy odkrywanie dróg do sukcesu.

\section{BIBLIOGRAFIA}

Dąbrowska A., Pasieka M., 2013, Potknięcia i omyłki kandydatów na lektorów języka polskiego jako obcego, w: J. Mazur, A. Małyska, K. Sobstyl (red.), Glottodydaktyka polonistyczna. W obliczu dynamiki zmian językowo-kulturowych i potrzeb społecznych, t. 1, Lublin, s. 241-252.

Newby D., Allan R., Fenner A.-B., Jones B., Komorowska H., Soghikyan K, 2007, Europejskie portfolio dla studentów - przyszłych nauczycieli języków, Warszawa.

Houssaye J., 2014, Le triangle pédagogique. Les différentes facettes de la pédagogie, Paryż.

Janowska I., 2012, Proces przystosowania materiałów dydaktycznych z języka polskiego jako obcego do zasad podejścia zadaniowego, „Postscriptum polonistyczne”, nr 2, s. 177-198.

Janowska I., 2014, Jak oceniać ustne działania językowe uczacych się? Ewaluacja wypowiedzi ustnej w podejściu ukierunkowanym na działanie, w: A. Mielczarek, A. Roter-Bourkane, M. Zduniak-Wiktorowicz (red.), Sukcesy, problemy, wyzwania w nauczaniu języka polskiego jako obcego, Poznań, s. 227-238.

Janowska I., 2015, Planowanie jednostek lekcyjnych i metodycznych - modele i schematy, „Postscriptum Polonistyczne", nr 2, s. 63-88.

Jedynak M., 2011, Europejskie portfolio dla studentów - przyszłych nauczycieli języków obcych a rozwijanie autonomii. Problemy z jego wdrażaniem wśród studentów filologii angielskiej, w: M. Pawlak (red.), Autonomia w nauce języka obcego - uczeń a nauczyciel, PoznańKalisz-Konin, s. 485-496.

Perrenoud Ph., 2012, Développer la pratique réflexive dans le métier d'enseignant, Paryż.

Rada Europy, 2003, Europejski system opisu kształcenia językowego: uczenie się, nauczanie, ocenianie, Warszawa.

Schön D., 1994, Le praticien réflexif. A la recherche du savoir caché dans l'agir professionnel, Montreal. 


\section{Iwona Janowska}

\section{METHODOLOGICAL MISTAKES IN PLANNING AND TEACHING CLASSES}

Keywords: mistake, foreign language teacher, teacher training, European standards, reflection

Summary. This paper is not a simple enumeration of teachers' mistakes although it discusses them often. Referring to the operational framework for teachers at various stages of the didactic process outlined in the European Portfolio for Student Teachers of Languages, we mainly focus on questions such as what teachers should do in specific - sometimes difficult - situations, what their roles or attitudes should be, what they should avoid, what they should pay special attention to, etc. The most typical drawbacks and shortcomings (as they are not countable or predictable) are presented in the context of negative consequences they cause as well as the remedies to be applied in order to prevent such anomalies in the future. A remedy that is often found effective in solving didactic issues we encounter in our daily work is a widely understood reflection on our own educational competencies and professional improvement. 